\title{
TATA LAKSANA GIZI HOLISTIK PADA PASIEN PENYAKIT GINJAL KRONIK DENGAN HIPERTENSI RAWAT INAP DI RSU HOLISTIC PURWAKARTA
}

\author{
Ahmad Yani1*, Nela Nursoleha ${ }^{2}$, Laila Fariha Zein ${ }^{3}$ \\ 1,2,3 Sekolah Tinggi Ilmu Kesehatan Holistik \\ *Korespondensi: Jl. Veteran No. 272 Purwakarta, Email: ahmadyani@holisticindonesia.com
}

\begin{abstract}
ABSTRAK
Latar Belakang: Prevalensi Penyakit Ginjal Kronik (PGK) semakin meningkat, etiologi PGK salah satunya adalah Hipertensi (HT). Tata laksana gizi berperan penting dalam membantu proses penyembuhan pasien. Keberhasilan tata laksana gizi ditentukan oleh efektivitas intervensi gizi melalui terapi diet, edukasi, dan konseling gizi yang efektif dan sesuai untuk pasien di rumah sakit.

Tujuan Penelitian: Penelitian ini bertujuan untuk mendeskripsikan penatalaksanaan diet holistik pada penderita PGK dengan HT di ruang rawat inap RSU Holistic Purwakarta.

Metode: Penelitian ini merupakan penelitian deskriptif dengan metode studi kasus. Subjek kasus adalah pasien PGK dengan HT dan memiliki riwayat penyakit SLE. Pemantauan kasus dilakukan selama lima hari, data yang dikumpulkan meliputi data primer, data sekunder, dan data hasil wawancara.

Hasil: Terapi diet yang diberikan adalah diet holistik penyakit ginjal dengan tahapan porsi kecil dan protein sangat rendah kurang dari $0,6 \mathrm{~g} / \mathrm{kgbb} /$ hari. Susunan menu terdiri dari bahan makanan alami dan organik. Proses pengolahan makanan minimal seperti direbus, dikukus, dan dipanggang sesuai kondisi pasien. Hasil pemantauan rata-rata intake makanan dengan tahapan porsi kecil adalah 100\% dengan komposisi zat gizi energi 161,71\%, protein 261,83\%, lemak 17,30\% dan karbohidrat 173,62\%. Hasil pemeriksaan laboratorium ureum $162 \mathrm{mg} / \mathrm{dL}$, kreatinin $6,8 \mathrm{mg} / \mathrm{dL}$, asam urat 11,9 $\mathrm{mg} / \mathrm{dL}$. Status gizi pasien normal $\left(22,53 \mathrm{~kg} / \mathrm{m}^{2}\right)$. Kondisi edema pasien berkurang ratarata cairan yang masuk dan keluar adalah $337 \mathrm{cc} /$ hari dan $1.146 \mathrm{cc} /$ hari. Tekanan darah sistolik menurun, namun tekanan darah diastolik meningkat 150/100 mmHg.

Simpulan: Tata laksana gizi holistik melalui intervensi terapi gizi dan edukasi diet holistik dapat meningkatkan kualitas diet pasien PGK dengan HT dan memiliki riwayat penyakit $S L E$.
\end{abstract}

Kata kunci: penyakit ginjal kronik, hipertensi, diet holistik

\begin{abstract}
Background: The prevalence of Chronic Kidney Disease (CKD) are getting increase. The etiology of CKD varies greatly with one of the most common cause is hypertension (HT). Nutritional management plays an important role in healing process of patients. The success of nutrition management is determined by the effectiveness of nutritional interventions through diet therapy, education, and counseling that are effective and suitable for patients in the hospital.

Objective: This research aims to determine the management of a holistic diet in patients with CKD and HT in the inpatient room of Holistic Hospital Purwakarta.

Method: This research is a descriptive study with a case study method. Case subjects were CKD patients with HT and had a history of SLE. Case monitoring was carried out for five days, data collected included primary data, secondary data and data from interviews

Results: Diet therapy for CKD patients started from small portions with lowest protein (less than $0.6 \mathrm{~g} / \mathrm{kgbw} /$ day). The menu consists of natural and organic food ingredients. Food processing uses minimal food process, such as boiled, steamed, and baked, according to the
\end{abstract}


patient's condition. The result showed that the average of food intake with small portion contains $100 \%$ nutrition, $161,71 \%$ energy, $261,83 \%$ protein, $17,30 \%$ fat, and $173,62 \%$ carbohydrate. The results of laboratory tests of urea is $162 \mathrm{mg} / \mathrm{dL}$, creatinine $6.8 \mathrm{mg} / \mathrm{dL}$, and uric acid $11.9 \mathrm{mg} / \mathrm{dL}$. Patient's body mass index (BMI) is classified as normal, which is $22.53 \mathrm{~kg} / \mathrm{m} 2$. The patient's edema condition is reduced, the average fluid intake and discharge are respectively $337 \mathrm{cc} /$ day and 1,146 cc/day. Systolic blood pressure decreases, while diastolic blood pressure increases up to 150/100 $\mathrm{mmHg}$.

Conclusion: Holistic nutrition management through nutritional therapy interventions and holistic diet quality of CKD patients with HT and have a history of SLE.

Keywords: chronic kidney disease, hypertension, holistic diet

\section{PENDAHULUAN}

Penyakit Ginjal Kronik (PGK) adalah kondisi hilangnya fungsi ginjal progresif dan ireversibel yang sangat mungkin mengancam jiwa pasien. Terjadi peningkatan jumlah penderita penyakit ginjal kronis, berdasarkan Riset Kesehatan Dasar (Riskesdas) 20131 ${ }^{1}$ prevalensi penyakit ginjal kronik di Indonesia sebesar 0,2\% dan hasil Riskesdas tahun 2018 sebesar $0,38 \% .^{2}$ Data profil Rumah Sakit Umum Holistic (RSUH) Purwakarta, PGK menempati sepuluh penyakit terbanyak pada tahun 2018 dengan jumlah pasien sebanyak 17 orang. Etiologi PGK sangat bervariasi, dengan penyebab terbanyak salah satunya adalah hipertensi (HT). Penyakit HT merupakan gangguan pada pembuluh darah yang mengakibatkan suplai oksigen dan zat gizi yang dibawa oleh darah terlambat sampai ke jaringan tubuh yang membutuhkan. Penyakit HT yang tidak ditangani dengan tepat menyebabkan gangguan fungsi ginjal.

Tata laksana gizi berperan penting dalam membantu proses penyembuhan pasien. Tujuan pemberian tata laksana gizi adalah mengembalikan pada status gizi baik dengan mengintervensi berbagai faktor penyebab. Keberhasilan tata laksana gizi ditentukan oleh efektivitas intervensi gizi melalui edukasi dan konseling gizi yang efektif dan sesuai untuk pasien di rumah sakit. ${ }^{3}$ Hasil penelitian yang dilakukan oleh Fernandes et al., ${ }^{4}$ menunjukkan pentingnya memfokuskan konseling makanan tidak hanya pada pembatasan gizi, tetapi memberikan pilihan makanan yang sehat yang bertujuan untuk meningkatkan kualitas diet keseluruhan pasien. Tata laksana gizi secara konvensional pada PGK dengan HT adalah mengontrol jumlah asupan protein dan garam. Tata laksana gizi pada PGK dengan HT di RSUH menggunakan pendekatan holistik dimana intervensi gizi menggunakan diet holistik. Diet holistik adalah diet yang memberikan makanan kepada pasien secara individual dengan mengutamakan bahan makanan alami dan minimal didalam proses pengolahan serta pembatasan protein dan garam yang sangat ketat. Hal ini dapat menjadi dasar perbedaan tata laksana gizi pada pasien, sehingga timbul pertanyaan bagaimana tata laksana gizi holistik pada pasien PGK dengan HT dan riwayat penyakit Systemic Lupus Erythematosus (SLE). Peningkatan asupan protein terbukti dapat mempengaruhi hemodinamik ginjal dan berperan terhadap kerusakan fungsi dan jaringan ginjal. Diet rendah protein memiliki peran penting dalam terapi PGK, terutama gagal ginjal kronik. Pada berbagai studi prosfektif diet protein sangat rendah secara nyata menurunkan progresifitas penyakit ginjal kronik, namun risiko malnutrisi meningkat pada pasien. ${ }^{5}$ Rhee et al., 20176 mengungkapkan diet rendah protein $(<0,4 \mathrm{gr} / \mathrm{kgbb} /$ hari $)$ bagi pasien PGK mampu meningkatkan manajemen perbaikan PGK dan dapat dijadikan alternative bagi pasien PGK yang ingin menghindari dialisis. Berdasarkan pertanyaan tersebut, maka penelitian studi kasus ini disusun untuk menjelaskan tata laksana gizi holistik pada kasus tersebut.

\section{METODE PENELITIAN}

Penelitian studi kasus ini bertujuan untuk menjelaskan tata laksana gizi holistik 
meliputi anamnesa gizi, diagnosa gizi, intervensi dan edukasi gizi serta melakukan monitoring dan evaluasi pada penderita PGK dengan HT. penelitian ini termasuk jenis penelitian deskriptif dengan metode studi kasus (case study). Penelitian ini dilaksanakan pada bulan Juli-Agustus 2019 di ruang rawat inap RSUH. Subjek penelitian adalah penderita PGK dengan HT dan memiliki riwayat penyakit SLE yang berjumlah 1 orang. PGK yang dimaksud adalah kerusakan ginjal $\geq 3$ bulan, kelainan struktur atau fungsi ginjal dengan atau

\section{HASIL PENELITIAN}

RSUH terletak di Jalan Terusan Kapten Halim KM 9 Desa Salam Mulya Kecamatan Pondok Salam Kabupaten Purwakarta. RSUH memiliki fasilitas layanan kesehatan meliputi layanan rawat jalan (IGD, poliklinik kebidanan, poliklinik kesehatan anak, poliklinik penyakit dalam, poliklinik bedah, poliklinik gigi dan mulut). Layanan rawat inap (pengawasan medis, asuhan keperawatan, tindakan/perasat medis dan perawatan yang sesuai dengan penyakit penderita, pelayanan gizi dan bila diperlukan pelayanan kerohanian oleh petugas yang ditunjuk). Tempat tidur yang tersedia 74 tempat tidur termasuk High Care Unit/Observasi. Ruang perawatan biasa terdiri dari: kelas Senior Suite 3, kelas Junior Suite 2, kelas eksekutif 9, kelas Deluxe 2, kelas VIP 5, kelas I 15, kelas II 16, kelas III 16, kelas HCU/Observasi 3, kelas VK 3. RSUH didalam layanan kesehatannya menggunakan metode layanan kesehatan holistik yaitu Holistic Medicine. Holistic Medicine adalah konsep pengobatan yang mengobati pasien secara menyeluruh dengan mengembalikan keseimbangan organ tubuh secara optimal melibatkan kerja fisik, psikis, mental, dan emosional dengan mengutamakan makanan/diet sebagai obat utama.

Pelayanan gizi holistik merupakan bagian dari layanan kesehatan holistik yang dilakukan berdasarkan keadaan klinis, status gizi, dan status metabolisme tubuh pasien. Layanan gizi rawat inap meliputi pengkajian gizi, diagnosa gizi, intervensi gizi holistik, serta monitoring dan evaluasi. Terapi diet holistik adalah pilar utama tanpa penurunan Laju Filtrasi Glomerolus (LFG). Pengumpulan data meliputi data primer (usia, jenis kelamin, pekerjaan, dan alamat), data kebutuhan zat gizi, dan data konsumsi zat gizi. Data sekunder yaitu data penyakit meliputi riwayat penyakit sekarang dan data hasil pemeriksaan laboratorium, yang diperoleh melalui medical record penderita dan data gambaran umum rumah sakit berdasarkan wawancara denga pihak manajemen RSUH.

dalam konsep pengobatan holistik di RSUH. Pilar pengobatan berikutnya adalah terapi fisik, mental, dan spiritual, terapi obat, dan suplementasi, serta kondisi lingkungan rumah sakit yang didesain sangat asri dan nyaman. Penyelenggaraan makanan di RSUH terdiri dari tiga kali makanan pokok dan tiga kali makanan selingan yang disesuaikan dengan siklus menu tujuh hari yang berlaku di rumah sakit. Jenis pendistribusian yaitu sentralisasi terpusat di Instalasi Gizi. Pendistribusian sentralisasi dilakukan untuk seluruh ruang perawatan. Standar porsi makanan pasien rawat inap untuk seluruh ruang perawatan dengan kategori Small-Medium-Large (SML) yaitu porsi kecil (small portion), porsi sedang (medium portion), dan porsi besar (large portion). Jadwal pendistribusian makanan untuk pagi hari yaitu pada pukul 06.0007.00 wib, selingan pagi pada pukul 09.0010.00 wib, makan siang pada pukul 12.0012.30 wib selingan sore pada pukul 15.3016.00 wib dan terakhir makan malam dan selingan malam pada pukul 17.00-17.30 wib. Pasien tidak diperkenankan membawa dan mengonsumsi makanan dari luar rumah sakit, kecuali makanan yang sudah direkomendasikan oleh dokter dan ahli gizi.

Subjek adalah Ny. B usia 37 tahun datang ke RSUH tanggal 26 Juli 2019 dengan keluhan sesak, lemas, mual namun tidak muntah, bengkak pada kedua tungkai, dan pegal-pegal. Subjek sulit buang air besar (BAB) dan sedikit buang air kecil (BAK). Pasien didiagnosis oleh Dokter Penanggung Jawab Pasien (DPJP) dengan CKD, HT, dan SLE. Satu minggu terakhir pasien mulai merasakan mual, asupan makanan hanya 12 kali per hari, lauk 1 potong kadang ayam goreng dan ikan mas atau tahu dan tempe, 
Journal of Holistic and Health Sciences

Vol.4, No.2, Juli-D e s e m b e r 2020 | 61

sayuran 1-2 porsi per hari, makanan selingan biskuit $1-2$ porsi dan 24 jam terakhir $1 / 2$ porsi makanan yang dihabiskan. Hasil anamnesa zat gizi subjek 24 jam terakhir di rumah sakit energi sebesar 848,56 kkal, protein 8,16 gr, lemak 0,08 gr dan karbohidrat 168,3 gr. Hasil pemeriksaan antropometri berat badan (BB) $51 \mathrm{~kg}$ dan tinggi badan (TB) $149 \mathrm{~cm}$ berdasarkan anamnesis dan pemeriksaan fisik, maka diagnosa gizi prioritas adalah penurunan kebutuhan protein berkaitan dengan gangguan fungsi ginjal ditandai dengan kadar ureum $162 \mathrm{mg} / \mathrm{dl}$, kreatinin $6,8 \mathrm{mg} / \mathrm{dl}$, asam urat $11,9 \mathrm{mg} / \mathrm{dl}$ dan edema. (NI-5.4). Menggunakan rumus Harris Benedict didapatkan kebutuhan energi
1.702 kkal, protein 15,30 gr, lemak 47,28 gr karbohidrat 291,17 gr. Makanan diberikan secara bertahap dimulai dari 50\% kebutuhan (small portion) yaitu 567,34 kkal, protein 5,10 gr, lemak 15,76 gr, KH 97,06 gr dalam bentuk makanan biasa. Subjek diberikan materi edukasi dan konseling gizi pertama kali masuk tentang penyakitnya dan bagaimana menjalankan diet holistik penyakit PGK dengan HT selama kurang lebih 60 menit.

Hasil pengukuran antropometri status gizi berdasarkan indeks masa tubuh (IMT) (grafik 1) subjek awal pengamatan adalah 22,98 kg/m² (normal) dan akhir pengamatan $22,53 \mathrm{~kg} / \mathrm{m}^{2}$.

\section{Grafik 1. Status Gizi Subjek Berdasarkan IMT}

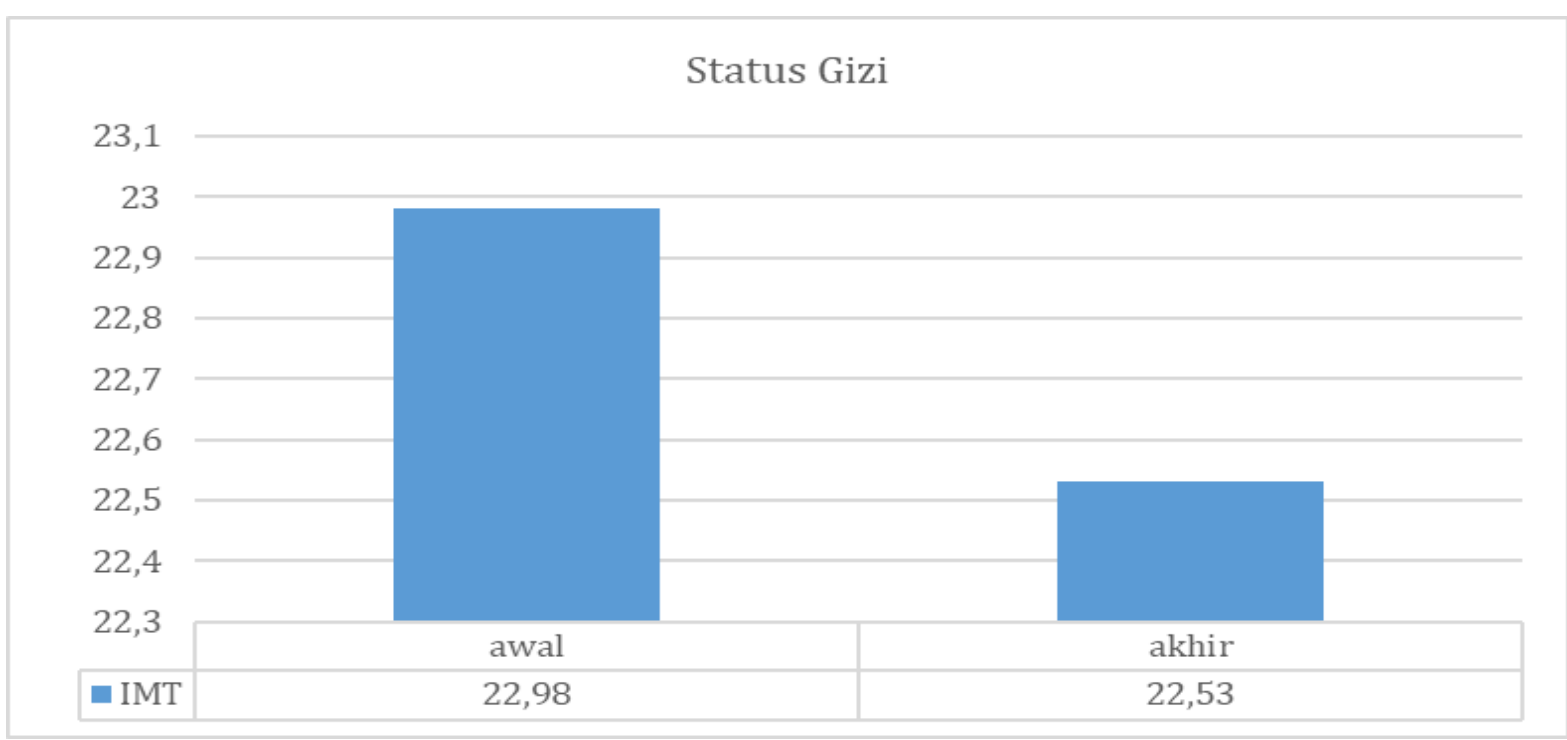

Sumber: Data Primer

Saat pemeriksaan awal (26 Juli 2019) didapatkan keadaan umum subjek tampak sakit sedang, dengan kesadaran kompos mentis tanda vital tekanan darah 160/90 $\mathrm{mmHg}$, nadi $77 \mathrm{x} /$ menit, laju pernapasan $20 \mathrm{x} /$ menit dengan suhu $37^{\circ} \mathrm{C}$. Hasil pemeriksaan klinis (Grafik 3.) subjek hari pertama pemantauan (H1), tekanan darah 160/90 mmHg, nadi 80x/menit, laju pernafasan $20 \mathrm{x} /$ menit, suhu $37^{\circ} \mathrm{C}$ dan akhir pemantauan (H5) tekanan darah 150/100 $\mathrm{mmHg}$ (nilai normal 120/80 mmHg), nadi 90x/menit (nilai normal 60-100x/menit), laju pernafasan 20x/menit (nilai normal 20$30 \mathrm{x} / \mathrm{menit}$ ), suhu $36^{\circ} \mathrm{C}$ (nilai normal 36$37^{\circ} \mathrm{C}$ ). Pemantauan dilakukan selama lima hari. Subjek mengalami perbaikan kondisi klinis berupa berkurangnya keluhan sesak, suhu tubuh turun $36^{\circ} \mathrm{C}$ namun tekanan darah masih tinggi. 
Journal of Holistic and Health Sciences

Vol.4, No.2, Juli-D e s e m b e r 2020 |62

\section{Grafik 2. Hasil Pemeriksaan Klinis Subjek}

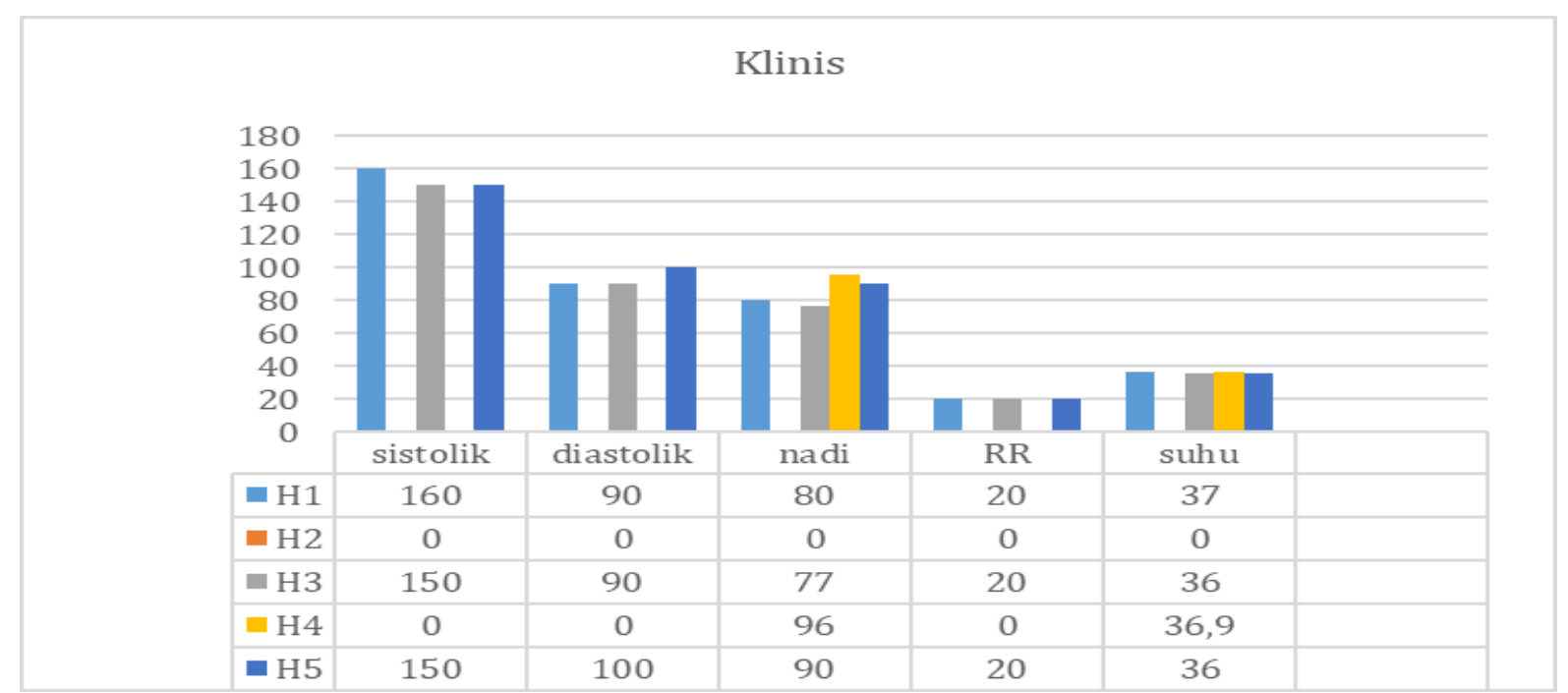

Sumber: Data Primer

Berdasarkan analisis asupan zat gizi subjek selama tiga hari pemantauan (Grafik 3.) asupan energi mengalami peningkatan di hari pertama (H1) 848,56 kkal, menjadi 966 kkal di hari kedua (H2), namun menurun lagi di hari ketiga (H3) 937,75 kkal; asupan protein hari pertama (H1) 14,45 gr, meningkat pada hari kedua (H2) 17,45 gr, namun menurun di hari ketiga (H3) 8,16 gr; asupan lemak hari pertama (H1) 3,3 gr, meningkat pada hari kedua (H2) 4,8 gr, dan menurun pada hari ketiga (H3) 0,08 gr; asupan karbohidrat hari pertama (H1) 155,15 gr, meningkat di hari kedua (H2) 168,4 gr, dan meningkat lagi pada hari ketiga (H3) 182 gr.

Grafik 3. Analisis Asupan Zat Gizi Subjek

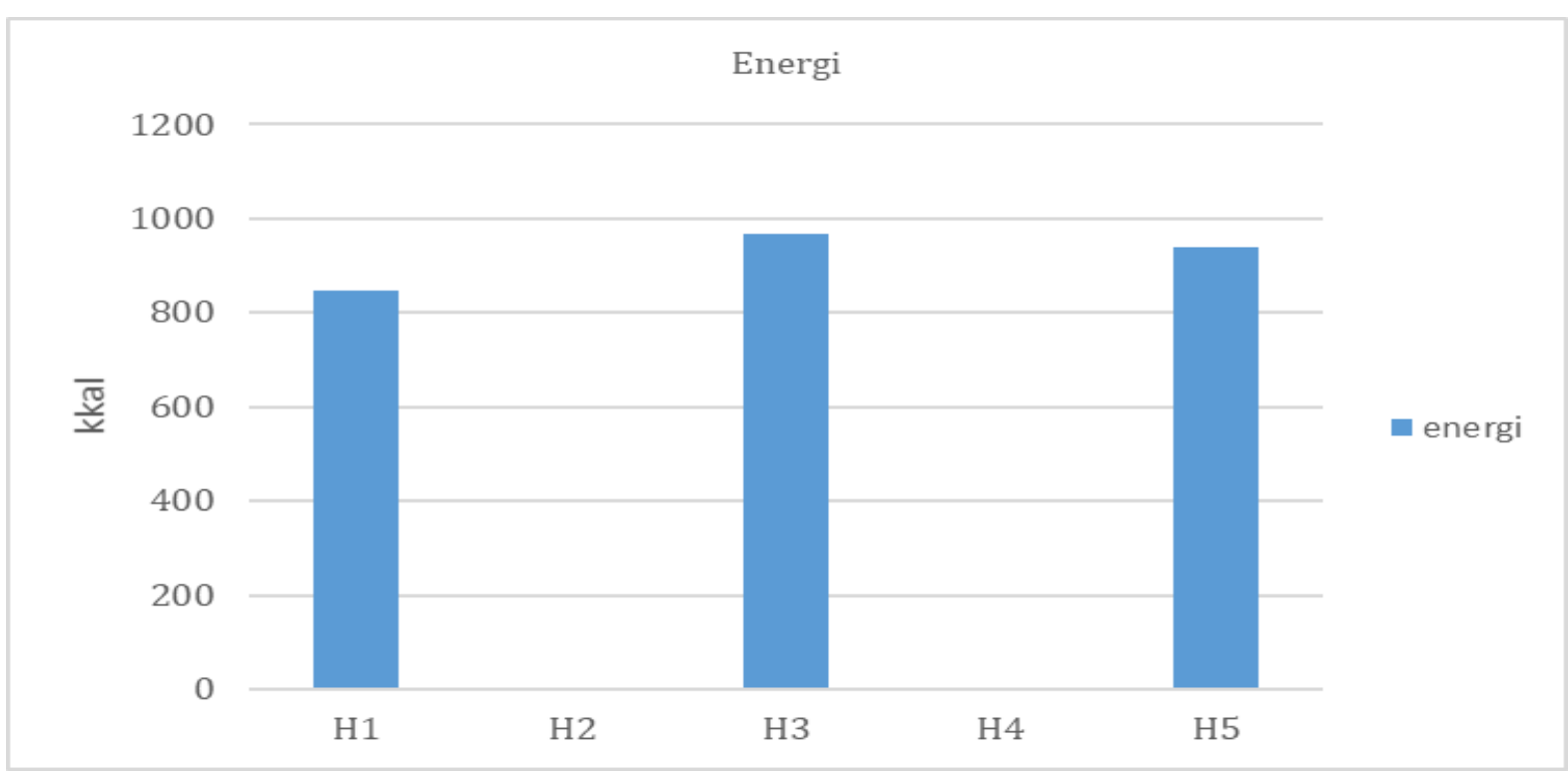


Journal of Holistic and Health Sciences

Vol.4, No.2, Juli-D e s e m b e r 2020 |63

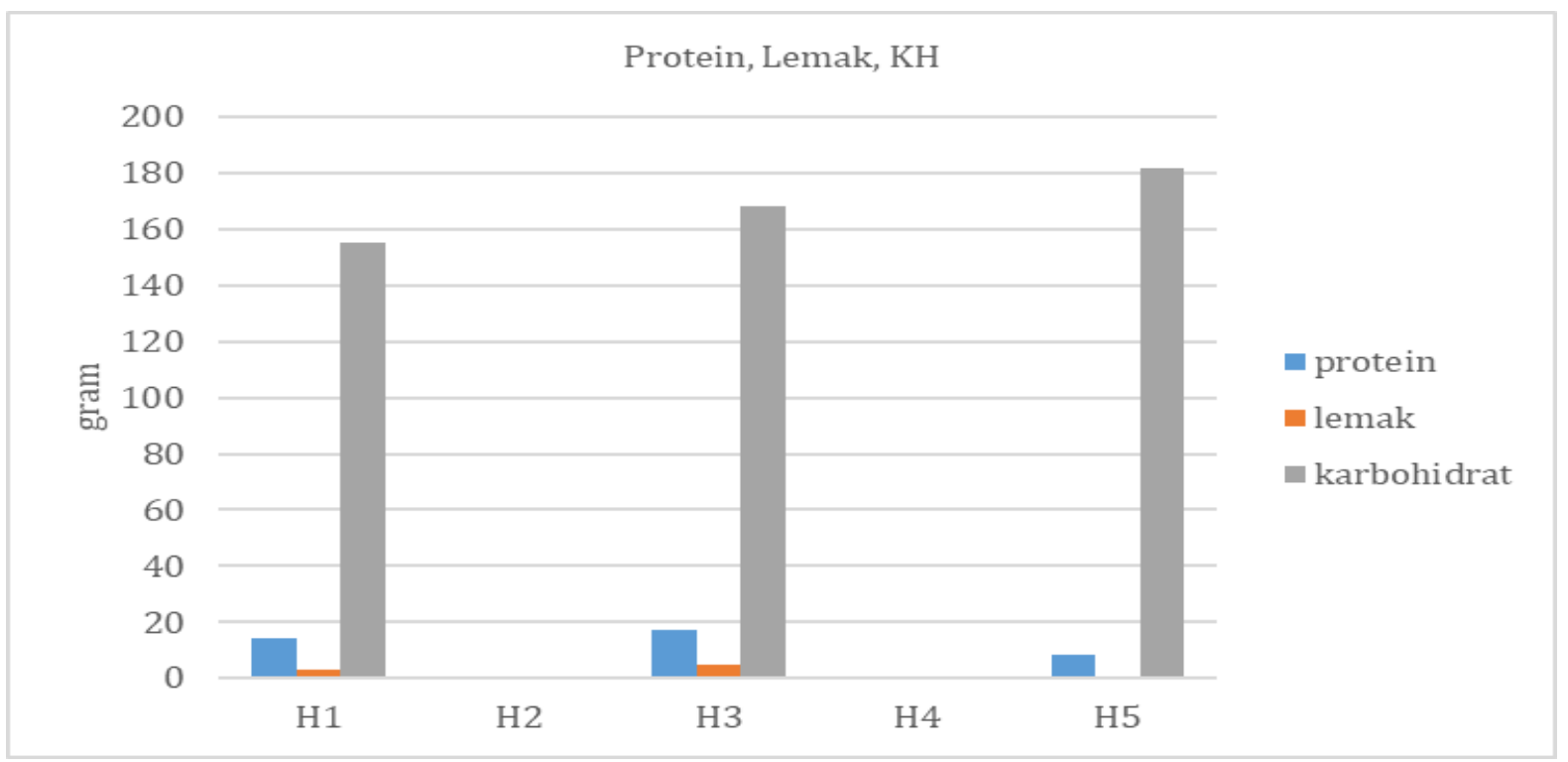

Sumber: Data Primer

Selama 5 hari pengamatan subjek hanya satu kali dilakukan pemeriksaan biokimia. Hasil pemeriksaan biokimia hemoglobin 7 $\mathrm{g} / \mathrm{dl}$ (nilai normal 12-15 g/dl), albumin 2,8 g/dl (nilai normal 3,7-5,2 g/dl), ureum 162 $\mathrm{mg} / \mathrm{dl}$ (nilai normal 0-50 mg/dl), kreatinin $6,8 \mathrm{mg} / \mathrm{dl}(0,5-1,2 \mathrm{mg} / \mathrm{dl}$, asam urat 11,9 $\mathrm{mg} / \mathrm{dl}$ (nilai normal 2,4-5,7 mg/dl).

\section{Grafik 4. Input, Output, dan Balance Cairan Subjek}

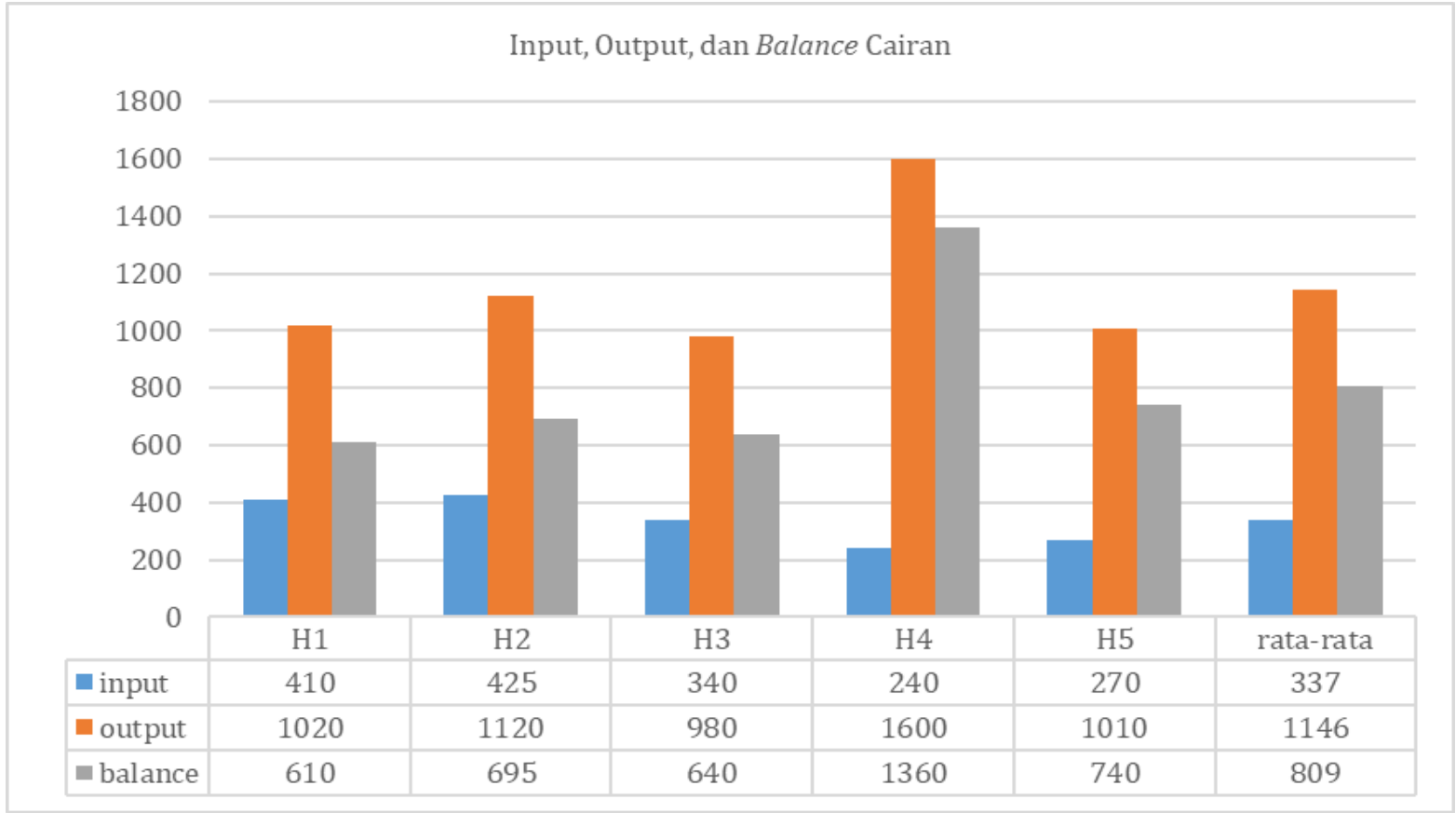

Sumber: Data Primer

Rata-rata input, output, dan balance cairan pasien sebanyak $337 \mathrm{cc} /$ hari, $1146 \mathrm{cc} / \mathrm{hari}$, dan 809 cc/hari.

\section{PEMBAHASAN}

Pasien masuk rumah sakit dengan keluhan sesak, lemas, mual, dan pegal-pegal. Pasien didiagnosa SLE empat tahun yang lalu yaitu tahun 2015. SLE adalah kelainan 
inflamantori multisistemik yang kronik, rekuren dan fatal sehingga sulit untuk didiagnosis. Hasil diagnosa DPJP pasien menderita penyakit ginjal kronik dengan hipertensi. Dari hasil pemeriksaan biokimia kadar ureum dan kreatinin tinggi (162 $\mathrm{mg} / \mathrm{dl}$ dan $6,8 \mathrm{mg} / \mathrm{dl}$ ). Faktor risiko terjadinya penyakit ginjal kronik yang tidak dapat dimodifikasi antara lain riwayat keluarga, penyakit ginjal, kelahiran prematur, usia, trauma/kecelakaan, jenis penyakit tertentu (SLE, Anemia, Kanker, AIDS, Hepatitis C, dan Gagal Jantung Berat). Faktor risiko yang dapat dimodifikasi antara lain Diabetes Mellitus tipe 2, Hipertensi, konsumsi obat pereda nyeri dan napza, radang ginjal.

Penyakit HT adalah penyakit yang dapat merusak pembuluh darah, jika pembuluh darahnya ada pada ginjal, maka ginjalnya akan mengalami kerusakan. Seseorang yang tidak mempunyai gangguan ginjal, tetapi meiliki penyakit hipertensi dan tidak diobati akan menyebabkan komplikasi pada kerusakan ginjal, dan kerusakan ginjal yang terjadi akan memperparah hipertensi. Banyak faktor yang menyebabkan subjek mengalami peningkatan systole dan atau diastole, peningkatan ini terjadi akibat dua parameter yang meningkat yaitu peningkatan tahanan perifer total tubuh dan peningkatan curah jantung (cardiac output). ${ }^{7}$

Subjek dengan penyakit ginjal kronik dan hipertensi, tingkat daya terima terhadap makanan yang disediakan rumah sakit tergolong kurang, hal ini disebabkan karena kondisi pasien yang masih merasa mual. Pasien menerima pemberian diet penyakit ginjal kronik dengan bentuk makanan biasa. Makanan diberikan sesuai dengan jadwal pendistribusian untuk makan pagi pukul 06.00, makan siang pukul 12.00 dan makan malam pukul 17.30. Ketepatan waktu pemberian makan merupakan salah satu indikator mutu dalam penyelenggaraan makanan rumah sakit.

Terapi diet yang diberikan adalah diet holistik penyakit ginjal dengan protein diberikan sangat rendah yaitu 0,3 $\mathrm{g} / \mathrm{kgbb} /$ hari. Terapi diet rendah protein atau Low Protein Diet (LPD) pada penyakit ginjal kronik diketahui memberi manfaat menurunkan akumulasi bahan buangan yang tidak dapat diekresikan oleh ginjal sehingga mengurangi gejala uremia, menurunkan proteinuria, dan memperlambat inisiasi Terapi Pengganti Ginjal (TPG). ${ }^{8}$ Namun retriksi protein yang terlalu ketat berimplikasi kepada risiko terjadi malnutrisi pada pasien PGK dan hal ini mempercepat progresivitas PGK. ${ }^{9}$

Menurut Rhee et al., 20176 melaporkan diet rendah protein (kurang dari $0,4 \quad \mathrm{gr} / \mathrm{kgbb} / \mathrm{hari}$ mampu meningkatkan manajemen perbaikan penderita PGK yang tidak bergantung pada dialisis dan dapat dianggap sebagai pilihan dan alternatif potensial bagi pasien PGK yang ingin menghindari dialisis dan memperlambat kerusakan ginjal.

Lee et al., 201910 menyatakan diet rendah protein bukan penentu utama pada PGK, namun kekurangan energi protein lebih mempercepat kerusakan ginjal, namun penerapan diet rendah protein, terutama diet sangat rendah protein disarankan untuk menambahkan penderita dengan $\alpha$-ketoacid atau asam amino esensial untuk menghindari malnutrisi. Suplemen $\alpha$ ketoacid lebih efektif daripada asam amino esensial dalam memperlambat perjalanan gangguan ginjal.

Penelitian Di Micco et al., 201911 diet rendah protein mampu mengurangi edema, diuretik, dan tekanan darah dengan diet rendah kandungan natrium, mengurangi dosis kadar fosfat dan pengikat fosfat serta memperlambat kerusakan PGK.

Diet holistik penyakit ginjal adalah terapi diet khas holistik untuk pasienpasien penyakit ginjal dan saluran kemih. Susunan menu mengacu pada menu alami dari bahan makanan alami dan organik. Bentuk makanan biasa yang minimal proses pengolahan seperti direbus, dikukus, dan dipanggang serta disesuaikan dengan kondisi pasien. Pemberian porsi makanan dilakukan dengan mengacu pada standar pemberian makanan di RSUH, yaitu small portion. Pemberian small portion dilakukan karena kondisi daya terima pasien terhadap makanan masih sangat kurang. Porsi pemberian makanan akan ditingkatkan secara bertahap sesuai kondisi daya terima pasien. Sumber karbohidrat berasal dari beras organik holistik, jagung, tepung beras organik dan umbi-umbian seperti kentang, 
singkong, ubi, talas. Sumber protein berasal dari hewani berupa telur ayam kampung, daging ayam kampung tanpa lemak dan ikan kembung serta sumber protein nabati yaitu tahu.

Tata laksana gizi untuk pasien penyakit gagal ginjal kronik bertujuan untuk memperbaiki kualitas hidup, menurunkan morbiditas dan mortalitas serta memperlambat progresivitas penyakit ginjal. ${ }^{5}$

Asupan zat gizi rata-rata subjek dengan tahapan pemberian makanan small portion yaitu $50 \%$ dari kebutuhan subjek untuk energi 567,34 kkal asupan rata-rata sebesar 917,44 kkal (161,71\%), kebutuhan protein 5,1 gr rata-rata asupan $13,35 \mathrm{gr}$ (261,83\%), dan kebutuhan karbohidrat 97,06 gr rata-rata asupan 168,52 $(173,62 \%)$, namun asupan lemak menurun 2,73 gr $(17,30 \%)$. Menurut National Kidney Foundation (NKF) Amerika bahwa pemberian porsi kecil pada makanan membantu asupan pasien PGK. ${ }^{12}$ Menurunnya asupan lemak disebabkan pembatasan protein yang ketat dan pengolahan makanan yang tidak diolah dengan minyak (rebus, kukus, dan panggang). Ando et al., $2015^{13}$ melaporkan penelitian tentang efek perebusan daging sapi, bahwa cara memasak dengan teknik perebusan mampu mengurangi kandungan fosfor dan lebih disukai oleh penderita PGK dan PGK dengan dialisis. Van Horn et al., $2016^{14}$ melaporkan bahwa pada pasien PGK perlu meminimalkan garam dan meminimalkan makanan olahan untuk mengurangi asupan natrium.

Makanan rumah sakit yang disesuaikan dengan kondisi pasien dan kebutuhan pasien serta adanya penyuluhan dan konsultasi sangat diperlukan guna memberikan motivasi kepada penderita untuk menghabiskan makanan yang disediakan sehingga diharapkan dapat meningkatkan intake zat gizi pasien. Menurut Widya S, et al., $2016^{15}$ gabungan konseling gizi secara individu dan kelompok dapat meningkatkan kualitas diet pasien.

\section{SIMPULAN}

Tata laksana gizi holistik pada penderita PGK dengan HT dan riwayat penyakit SLE dengan memberikan diet holistik protein sangat rendah $(0,3 \mathrm{gr} / \mathrm{kgbb} / \mathrm{hari})$ diberikan secara bertahap Small portion, Medium portion, Large portion (SML) serta edukasi dan konseling gizi yang efektif dapat meningkatkan kualitas diet pasien. Perlu dilakukan penelitian lebih lanjut dengan desain eksperimental pre-post test untuk memantau pengaruh diet holistik terhadap kondisi pasien secara nyata.

\section{DAFTAR PUSTAKA}

1. Kementrian Kesehatan Republik Indonesia. Riset Kesehatan Dasar. 2013. Diakses dari Laporan Hasil Riset Kesehatan Dasar (Riskesdas) | Badan Penelitian dan Pengembangan Kesehatan (kemkes.go.id)

2. Kementrian Kesehatan Republik Indonesia. Riset Kesehatan Dasar. 2018. Diakses dari Laporan Hasil Riset Kesehatan Dasar (Riskesdas) | Badan Penelitian dan Pengembangan Kesehatan (kemkes.go.id)

3. Kementerian Kesehatan Republik Indonesia. Buku Pedoman Proses Asuhan Gizi Terstandar. Jakarta: Kementerian Kesehatan RI; 2014

4. Fernandes, A. S., Ramos, C. I., Nerbass, F. B., \& Cuppari, L. Diet Quality of Chronic Kidney Disease Patients and the Impact of Nutritional Counseling. Journal of Renal Nutrition. 2018; 28 (6): 403-410. https://doi.org/10.1053/j.jrn.2017.10 .005

5. Indonesia, P. N. PERHIMPUNAN NEFROLOGI INDONESIA ( $P$ E R N E FR I). 2011.

6. Rhee, C. M., Ahmadi, S. F., Kovesdy, C. P., \& Kalantar-Zadeh, K. Low-Protein Diet for Conservative Management of Chronic Kidney Disease: A Systematic Review and Meta-analysis of Controlled Trials. Journal of Cachexia, Sarcopenia and Muscle. 2018; 9: 235245. https://doi.org/10.1002/jcsm.12264.

7. Bellizzi, V. Low-Protein Diet or Nutritional Therapy in Chronic Kidney Disease?. Blood Purification. 2013; 36:41-46. https://doi.org/10.1159/000350585 
8. Fouque, D. Low Protein, Amino Acid and Ketoacid Diets to Slow the Progression of Chronic Kidney Disease and Improve Metabolic Control of Uremia. Nutritional Management of Renal Disease. 2013:209-231.

https://doi.org/10.1016/B978-0-12391934-2.00014-X

9. Rahardjo, P. Hubungan Hipertensi dengan Penyakit Ginjal. 2015. Diakses dari http://ikcc.or.id/healthtips/hubungan-hipertensi-denganpenyakit-ginjal/.

10. Lee, S. W., Yong-Soo Kim, Yeong Soo., Kim., Wookyung Chung, Sue K. Park. et al. Dietary Protein Intake, Protein Energy Wasting, and the Progression of Chronic Kidney Disease: Analysis from the KNOW-CKD Study. Nutrients. 2019; $11 \quad$ (1) ;121. https://doi.org/10.3390/nu1101012 1

11. Di Micco, L., Di Lullo, L., Bellasi, A., \& Di Iorio, B. R. Very Low Protein Diet for Patients with Chronic Kidney Disease: Recent Insights. Journal of Clinical Medicine. 2019; 8 (5):718. https://doi.org/10.3390/jcm8050718

12. National Kidney Fondation Amerika. Potassium and Your CKD Diet. 2018. Diakses dari https://www.kidney.org/atoz/conten $\mathrm{t} /$ potassium

13. Ando, S., Sakuma, M., Morimoto, Y., \& Arai, H. The Effect of Various Boiling Conditions on Reduction of Phosphorus and Protein in Meat. Journal of Renal Nutrition. 2015; 25 (6):504-509. https://doi.org/10.1053/j.jrn.2015.05 .005

14. Van Horn, L., Jo Ann S. Carson, Lawrence J. Appel., Lora E. Burke., Christina Economos., Wahida Karmally. et al. Recommended Dietary Pattern to Achieve Adherence to the American Heart Association/American College of Cardiology (AHA/ACC) Guidelines: A Scientific Study from the American Heart Association. Circulation. 2016; 134(22):505-529. https://doi.org/10.1161/CIR.000000 0000000462

15. Widya S, S., Budi P, L., \& Purba, M. B. Konseling Gizi Mempengaruhi Kualitas Diet Pasien Diabetes Mellitus Tipe 2 di RSUP Dr.Sardjito Yogyakarta. Jurnal Gizi Dan Dietetik Indonesia (Indonesian Journal of Nutrition and Dietetics). 2016; 3(1):31-40. https://doi.org/10.21927/ijnd.2015.3 (1).31-40 